TAPROBANICA, ISSN 1800-427X. August, 2014. Vol. 06, No. 02: pp. 79-82.

(C) Research Center for Climate Change, University of Indonesia, Depok, Indonesia \& Taprobanica Private Limited, Homagama, Sri Lanka http://www.sljol.info/index.php/tapro

\title{
RESURRECTING THE TYPE LOCALITY OF Ceropegia odorata (APOCYNACEAE) AFTER 175 YEARS
}

\footnotetext{
${ }^{1}$ Botanical Survey of India, Central Regional Centre, 10, Chatham Lines, Allahabad 211002, U. P., India E-mail: rksbsiadsingh@yahoo.co.in

${ }^{2}$ Botanical Survey of India, Western Regional Centre, 7, Koregaon Road, Pune 411 001, Maharashtra, India
}

\begin{abstract}
The type locality of the critically endangered Ceropegia odorata Nimmo ex J. Graham is resurrected after a lapse of about 175 years. A detailed description, distribution, habitat, IUCN threat status, and a nomenclatural note are provided along with a neotype designation. The main threat factors responsible for dwindling of populations of the species are discussed and measures are suggested to arrest the operative causal factors.
\end{abstract}

Key words: Borivali NP, critically endangered, fragrant flower, Maharashtra, neotype, Salsette Island

\section{Introduction}

Many of the remarkable Ceropegia L. (Apocynaceae) species in India - 'the centre of origin and cradle of Ceropegia', are disappointedly getting siphoned into pages of the Red Data Book for want of human concern and awareness. One such critically endangered species, Ceropegia odorata Nimmo ex J. Graham (1839), had gone extinct from its type locality soon after the type collection (Nayar \& Sastry, 1987) was made by Joseph Nimmo (1819-1854) from Salsette Island (Mumbai).

After a lapse of nearly a century and a half $\mathrm{S}$. D. Sabnis and S. J. Bedi, in 1971, rediscovered Cerioegua odorata from the Pavagadh Hills,

Panchmahal District in Gujarat but did not comment upon the fragrant aspect of the flowers. Subsequently the species was not found in this locality. A decade later, in 1982, M. Y. Ansari located this species, with fragrant flowers, in a new site at Melghat, Amravati District in Maharashtra. This led to the authentication of Nimmo's observation of "fragrant yellow" flowers of $C$. odorata and finally after about one and a half century of uncertainty confirmed that the flowers in $C$. odorata were fragrant. Further, during his study of the Ceropegia specimens at CAL, Ansari identified two sheets, one of Col. Poulett from Mount Abu, Rajasthan, dated 1891, and another 
gathered by Gibson from Bombay Presidency, to be $C$. odorata. These findings suggested the species was found in four sites: the Pavagadh Hills in Gujarat, Mount Abu in Rajasthan, Salsette Island, and at Melghat in Maharashtra.

From 2007 to 2013 field surveys were conducted to assess the current status of Ceropegia odorata in all the above sites as well as throughout the Western Ghats in Goa, Karnataka, and Maharashtra, keeping track of the specific habitat types. Alarmingly, by the year 2012 there was no individuals extant in the Pavagadh Hills and on Mount Abu except in Melghat where a population consisted of only about 15 individuals. In July 2012, three additional sites were discovered from the Ratnagiri District in Maharashtra each with minimal populations: Bhoste Ghat, Khed $\left(17^{\circ} 42^{\prime} 37.02^{\prime \prime} \mathrm{N}, 7^{\circ} 24^{\prime} 00.46^{\prime \prime} \mathrm{E}\right)$ having about ten individuals, Matwan, Dapoli $\left(17^{\circ} 49^{\prime} 53.54^{\prime \prime} \mathrm{N}, 73^{\circ} 17^{\prime} 11.43^{\prime \prime} \mathrm{E}\right)$ with some 25 individuals, and Hativale $\left(16^{\circ} 37^{\prime} 14.95^{\prime \prime} \mathrm{N}\right.$, $\left.73^{\circ} 32^{\prime} 16.43^{\prime \prime} \mathrm{E}\right)$ with about 15 individuals. Amazingly, in the subsequent year (August 2013) this species was rediscovered in the type locality, Borivali, Mumbai, in the vicinity of the Sanjay Gandhi National Park at $19^{\circ} 12^{\prime} 47.55^{\prime \prime} \mathrm{N}$, $72^{\circ} 54^{\prime} 19.72^{\prime \prime} \mathrm{E}$ at about $160 \mathrm{~m}$ above sea level, with an extant population of approximately 20 individuals. This finding resurrected the type locality of $C$. odorata after a lapse of about one hundred and seventy-five years, a long time span during which all hopes of existence of the type locality had vanished.

The genus Ceropegia L., with around 200 species distributed throughout the world, has its highest endemism of up to $18 \%$ in Western Ghats (36 entities) of which 50\% (18 entities) are strictly endemic to Maharashtra (Diwakar \& Singh, 2011; Kambale et al., 2012). However, the type localities of almost all of these endemics are perpetually exposed to pressures from anthropogenic interferences due to regular developmental activities in the Ghats and plateaus for picnic and recreational spots, cattle grazing, and the removal of edible and medicinal tubers. Such stochastic perturbations coupled with encroachment and urbanisation led Mishra \& Singh (2001) to conclude that the extinction was the fate of at least two species, $C$. jainii Ansair \& Kulk. and C. odorata. Although to our delight, while the type locality of the latter species is rediscovered now, this may not be possible in other cases. Furthermore, since there is a drastic decline of the population structure of the 18 endemics of Ceropegia in Maharashtra by $80-90 \%$, the time is not far when the operational factors also shall annihilate the remaining type localities. Under these conditions the resurrected type locality of C. odorata is also prone to revert to its earlier 'extinct' status under the influence of expanding urbanisation and clearing of the few forested patches still extant around the Mumbai precincts. Conservation of this scanty population within its estimated $500 \mathrm{sq} . \mathrm{m}$ area is therefore of immediate concern.

Ceropegia odorata Nimmo ex J. Graham, 1839 Cat. Pl. Bombay: 118. Jun-Dec 1839. (Fig. 1)

Neotype (here designate): India, Maharashtra, Salsette Island (Mumbai), Concan (Konkan), November 1847, J. S. Law 239 (K!).

Herbs slender, twining, tuberous. Stems usually glabrous, sometimes sparsely pubescent. Leaves $2-12 \times 0.5-5 \mathrm{~cm}$, opposite; petioles $0.5-2 \mathrm{~cm}$ long, glabrous; blades linearlanceolate or lanceolate-narrowly ovate, acuminate at apex, rounded or acute at base, ciliate along margins, usually puberulous above and along the nerves beneath, sometimes glabrous on both surfaces; nerves prominent beneath. Inflorescences in axillary, 3-12flowered umbellate cymes; peduncles $0.5-3 \mathrm{~cm}$ long, hirsute, greenish yellow and sometimes with a purplish tinge. Flowers $3-8 \mathrm{~cm}$ long, yellowish green, fragrant, bracteate; pedicels $0.5-1 \mathrm{~cm}$ long, usually glabrous, rarely pubescent; bracts $0.5-1 \mathrm{~cm}$ long, linear. Calyx $0.5-0.8 \mathrm{~cm}$ long, linear, acuminate, glabrous. Corolla 3-7 cm long, yellowish green, sometimes with purplish tinge on tube; tube $1.5-4 \mathrm{~cm}$ long, inflated near base; lobes $1.5-3$ $\mathrm{cm}$ long, equal or shorter than tube; outer corona of five entire lobes, glabrous; inner corona linear-oblong, erect, divergent at apex.

Nomenclatural note: The above neotype is required as the original Nimmo gathering is not known to exist. The neotype gathering was cited by Joseph D. Hooker (Fl. Brit. India 4 (10): 85. Jun 1883) when he described Ceropegia odorata in far more detail than Graham. This place of publication has, until now, been considered the first place of valid publication. *See editor's end note below. 
Flowering and fruiting: July-November. Illustration: Sabnis \& Bedi, l. c.

Habitat: Grows in open area in outskirts of forests and steep hilly slopes among bushes in gravelly soils.

Distribution: Endemic to Gujarat (Pavagadh Hills, Panchmahal District), Rajasthan (Mount Abu, Sirohi District), and Maharashtra (Bhoste Ghat, Khed, Ratnagiri District; Hativale, Ratnagiri District; Matwan, Dapoli, Ratnagiri District; Sanjay Gandhi National Park, Borivali, Mumbai; Tarubanda forest, Melghat, Amravati District). At present no individuals are known from the Pavagadh Hills and at Mount Abu; only extant at five localities in Maharashtra State viz. Bhoste Ghat, Borivali, Hativale, Matwan and Melghat.

Specimens examined: Maharashtra, Salsette Island (Mumbai), Concan (Konkan), Nov 1847, J. S. Law 239 (K-neotype); Maharashtra, Concan (Konkan), sin. dat., J. S. Law s.n. (K); Rajasthan, Mount Abu, Aug 1891, Col. Poulett s.n. (CAL); Bombay Presidency, sin. dat., G. S. Gibson s.n. (CAL); Maharashtra, Amravati, Melghat, Tarubanda forest, Aug 1965, M. Y. Ansari 149304 (BSI); Maharashtra, Ratnagiri, Khed, Bhoste Ghat, 20 Jul 2012, S. Patil \& J. S. Jalal 200493 (BSI); Maharashtra, Ratnagiri, Hativale, 21 Jul 2012, S. Patil \& J. S. Jalal 200496 (BSI); Maharashtra, Ratnagiri, Matwan, 24 Aug 2012, S. Patil \& J. S. Jalal 195032 (BSI); Maharashtra, Mumbai, Borivali National Park, 18 Aug 2013, S. Patil \& J. S. Jalal 195031 (BSI).

Threat factors: 1 . The attractive flowers catch the attention of people hence face anthropogenic disturbances; 2. The flower structure is highly complicated which drives off the pollinators, coupling their scanty flower density in small population size; 3. Any crossing which occurs also amounts to inbreeding due to the narrow restricted population size; 4 . The ramet population is perpetuating by means of the deeply penetrating tubers, having edible and medicinal properties which are dug out by local people for their routine use; and, 5. Seed germinability is negligible as among the entire populations only few flowers produced follicles and even the majority of their seeds failed to germinate insitu as well as under $e x$-situ conditions.
Measures for conservation: 1. The anthropogenic disturbances may be avoided as the first step to safeguard the extant miniature population, simply by fencing and strictly restricting encroachment; 2. Digging out of tubers by local dwellers needs to be banned completely and general awareness created in this direction on the botanical significance of these species; and, 3. Species' multiplication through culture techniques may be acquired as this method relies on regeneration of plants through other vegetative parts using minimal plant material. Thus damage to the population is avoided because uprooting of even a single tuber shall further decimate the population and is not advisable for experiments. The juvenile plantlets after acclimatization can be reintroduced in their natural habitat and then monitored for successful establishment in wild.

IUCN threat status: Based on assessment and field observations from 2007 to 2013, Ceropegia odorata is currently categorised as Critically Endangered [B2b (i,ii,iii,v) c (i,ii,iv)].

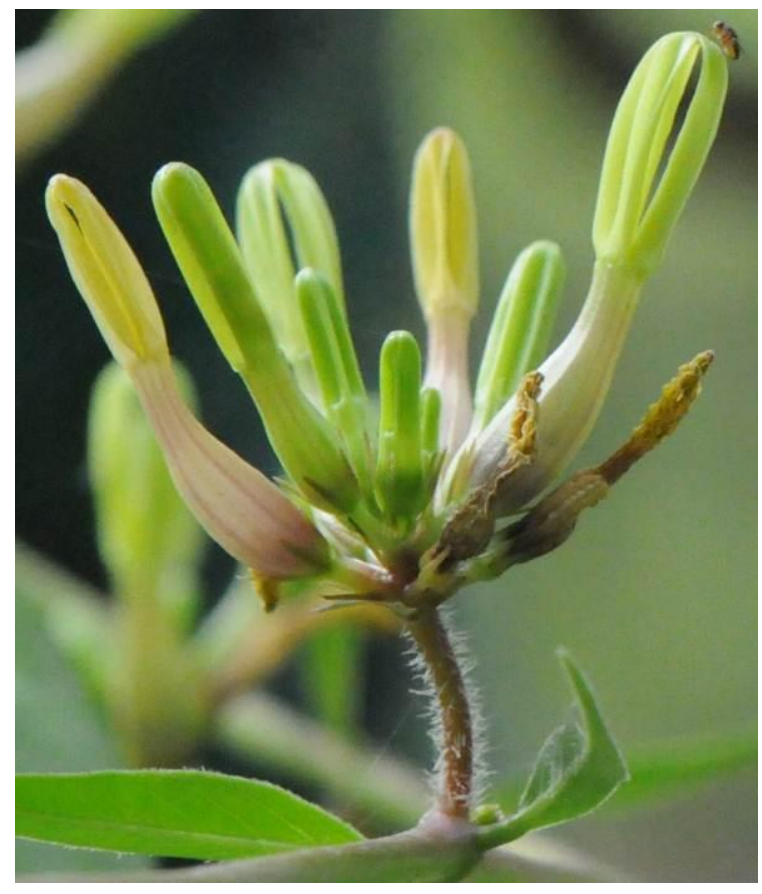

Figure 1: Ceropegia odorata Nimmo ex Hook. f.

\section{Acknowledgements}

The authors are thankful to the Director (BSI), and Head of Office (BSI), Central Regional Centre, Allahabad for facilities. We are also grateful to the Forest officials of Goa, Gujarat, Karnataka, Maharashtra and Rajasthan for their generous support in field exploration. 


\section{Literature Cited}

Diwakar, P. G. and R. Kr. Singh, 2011. A new variety of Ceropegia attenuata Hook. (Asclepiadaceae) from Mookambika Wildlife Sanctuary, Karnataka, India. Indian Journal of Forestry, 34: 209-212.

Graham, J. 1839. A Catalogue of the Plants Growing in Bombay and its Vicinity; Spontaneous, Cultivated or Introduced, as far as they have been Ascertained Government Press, Bombay: 118.

Hooker, J. D., 1883. The Flora of British India. L. Reeve \& Company Ltd., London, Vol. 4: 75.

McNeill, J., F. R. Barrie, W. R. Buck, V. Demoulin, W. Greuter, D. Hawksworth, P. S.Herendeen, S. Knapp, K. Marhold, J. Prado, , W. F. Prud-Homme van Reine, G. F. Smith, J. H. Wiersema, and N. J. Turland, 2012. International Code of Nomenclature for algae, fungi and plants (Melbourne Code). Regnum Vegetabile, 154: 1240.

Mishra, D. K. and N. P. Singh, 2001. Endemic and Threatened Flowering Plants of Maharashtra. Botanical Survey of India, Kolkata: 145-146.

Nayar, M. P. and A. R. K. Sastry, 1987. Red data book of Indian plants. Botanical Survey of India, Calcutta, Vol. 1: 49-71.

Sabnis, S. D. and S. J. Bedi, 1971. Ceropegia odorata Hook. f. (Asclepiadaceae) - a little known plant of western India. Kew Bulletin, 25: $57-59$.

*Editor's end note: Traditionally the 1839 name proposed by John Graham based on the now lost Joseph Nimmo collection has been considered inadequate and thus Ceropegia odorata was not validly published at that time. This is not true. The phrase used by Graham (1839), "Flowers yellow, fragrant, so unusual in this genus", is brief but under provisions of Art. 38.1 of the International Code of Nomenclature for algae, fungi, and plants (McNeill et al., 2012) this is adequate as all that is required by the Code is that a description or diagnosis be present. While this species of Ceropegia does not have yellow flowers but yellowish green flowers like all of the species known from India prior to 1839 , this is still a descriptive phase. Much more important here, as pointed out by
Singh et al. (in this paper), fragrant flowers are unique to this species and thus diagnostic. In this case, the word "fragrant" modifies flowers and therefore is not a "purely aesthetic" feature as defined in Art. 38.3. The section editor wishes to thank John McNeill (E) for his assistance in this matter. 